\title{
Operating Urban Elements for Cities in Transition from Socialism to Capitalism
}

\author{
Višnja Kukoč
}

University of Split, Faculty of Civil Engineering, Architecture \& Geodesy, Urban Planning Department, Matice hrvatske 15, 21000 Split, Croatia

\begin{abstract}
The main research topic is the city in the period of transition from socialism to capitalism and the associated attitudes towards urban planning. A case study was conducted on the city of Split, in particular the area called Split 3. The aim was to establish the mode of operating in contemporary conditions of urban planning and reconstructing small cities of up to 300,000 inhabitants by learning from local good practices. We used textual and graphic materials as the basis for exploring the programming, planning and realization of city construction for 50,000 inhabitants that took place during socialism, and its subsequent development under capitalism. Establishing usability of the then forms in present-day life followed. To this end, we analyzed the neighborhood unit proposed by C.A. Perry in 1929, the typical neighborhood proposed by the Urban Task Force headed by Richard Rogers in 1999 and the fused grid proposed by the Victoria Transport Policy Institute in Canada in 2012 - and compared it with the urban unit used in Split 3.

In the concluding section we extracted common elements and common dimensions of analyzed units and proposed them as references of the operation of modern urban planning and reconstruction of small towns of up to 300,000 inhabitants, bearing in mind that "Cities are an immense laboratory of trial and error, failure and success, in city building and city design. This is the laboratory in which city planning should have been learning and forming and testing its theories" [1].
\end{abstract}

Keywords: Urban unit, neighborhood unit, city, street, urban planning.

\section{INTRODUCTION}

“...a noble logical diagram once recorded will never die; long after we are gone it will be a living thing, asserting itself with ever-growing insistency..."

Burnham H Daniel, London, 1910 [2].

In European countries that moved from socialism to capitalism the comparison of urban planning and construction of a city under two different social systems arises. In our research we are concerned with socialism in the former Yugoslavia, also called self-managed socialism and social or socialistic self-management, which was characterized by a one-party system and social ownership as opposed to the state ownership in the former Soviet Union (USSR) and other Eastern bloc countries. The Yugoslavian system was decentraliszd (into six socialistic republics) and it recognized some elements of the market economy. "Dying out of a state and property rights, and the establishment of self-management as a basic organizing principle of the former Yugoslav socialistic society were already introduced by Constitutional Law in

*Address correspondence to this author at the University of Split, Faculty of Civil Engineering, Architecture \& Geodesy, Urban Planning Department, Matice hrvatske 15, 21000 Split, Croatia; Tel: +385 (0) 917850093 ;

E-mail: visnja.kukoc@gradst.hr
1953. Education, culture, science, health and social security were separated from the state domain and transferred to selfgoverning bodies" [3].

Socialism lasted from the end of the Second World War in 1945 to 1991, two years after the fall of the Berlin Wall.

To observe changes in a city over a long period of several decades we chose Split, Croatia's second largest city, and in particular the area called Split 3 . This city provided us with a rare opportunity as notable construction of a new part of the city for 50,000 inhabitants took place in the late 1960s. We first analyzed the urban elements of Split 3 and then urban elements created elsewhere, under capitalism.

In that regard, we argue that urban planning is not related to social systems. "The problems of urbanism are indeed general. There is only specific emphasis of this or that society on certain aspects of the problems" [4]. "It seems that the socialist city currently does not offer a significant alternative in the process of urban growth" [5]. "Urban issues are global, but the way of approaching them depends on the vocational, social and political structures of countries, as well as the ideological superstructure" [6].

We argue that urban elements such as the neighborhood unit and the street - i.e., public spaces - are to be used as constants in urban planning in small cities. "To a far greater 
extent than private commercial arenas, a public democratically managed city provides access and opportunities for all groups of society to express themselves and latitude for nonmainstream activities" [7].

\section{MATERIALS AND METHODS}

For the purpose of the study of Split development, we analyzed both textual and graphic materials as well as the direct method of verifying the situation on the ground. We conducted the textual study through brochures, special publications and professional journals written over the last 40 years of the city's existence. The graphic research consisted of comparing plans and provisions of the planning of Split, developed from 1945 to the late 1980s, with existing conditions in 1989 and 2009.

The concluding section of research was comparative: We evaluated the elements of the concept of the entire Split 3 project with elements of the neighborhood unit proposed by C.A. Perry in 1929, elements of the typical neighborhood proposed by the Urban Task Force headed by Richard Rogers in 1999 and elements of the fused grid proposed by the Victoria Transport Policy Institute in Canada in 2012.

\section{RESULTS}

\section{Cities}

Cities look alike, no matter how they originate. In cities people work, create new ideas, enjoy cultural events, go to school, play sports, practice their faith. The city is an ongoing phenomenon, created for the purposes of human encounter. Man has a need to see and to be seen, to create and to be fulfilled in relation to others. The city is a meeting place for people and ideas, for the exchange of goods and information. Only through direct contact do new values, new knowledge and new skills appear.

The definition of a city is broad. The word is used for Hong Kong, which has about seven million inhabitants; Rome, with its approximately three million inhabitants; and Split, which has roughly 200,000 inhabitants. But the differences are self-evident. Big cities are complex organisms. Some of them grow with a speed that is counted by hourly inhabitant growth. Small cities - from tens of thousands to several hundred thousand inhabitants - grow at a slower pace. Yet they still can be understood and their development controlled.

Since big cities have long outgrown urban measure and therefore, they no longer reflect the relationship between man and space. They rose above urban design and environmental considerations. Today, Aristotle's idea, confirmed by Camillo Sitte in the early $20^{\text {th }}$ century, that "towns should be built so as to protect their inhabitants and at the same time make them happy" [8], is incomprehensible. New concepts, new technology, new vocabulary and new names are sought for big cities. Until recently, terms such as meta-cities, multicities and scattered cities were in use, whereas nowadays it is "smart cities (villes intelligentes)" and "digital cities (villes numériques)" [9].
Cities in the states that succeeded the former Yugoslavia have mostly up to 300,000 inhabitants (with the exception of Zagreb, Belgrade, Skopje and Sarajevo), making them small cities.

\section{CITIES DURING SOCIALISM}

In the former Yugoslavia, the majority of goods, manmade goods and natural resources were socially owned. The planning and realisation of public places and public programmes were the main concern in urban planning, since private property in real estate in cities was limited. Terms such as social development, social values and social projects were used. Urban planning was considered a social activity. Public places and public programs were dimensioned according to the expected growth of the number of inhabitants and the planned development of the economy. Individual and private initiative was not formally recognised by the system. With the change in Croatia's social system, which occurred in 1991, social property has become state property. Market and private capital have become crucial for enterprises in the construction industry. Instead of community development, the focus shifted to the profitability of the investment.

In Split, the changes in the planning and implementation of construction are vivid, if we compare the socialist era that lasted until 1991 and the development of capitalism from 1991 to 2014 . We consider the past 23 years a transitional phase because the former method of planning public places could no longer be applied and a new approach has not been established in its final form.

Throughout history, social conditions in Europe have shared a common denominator. In the period from 1945 to 1990, the situation diverged in two opposing directions. After the Second World War, in several Eastern European countries socialism based on state ownership and the one-party system appeared. In Yugoslavia, one-party socialism was established as well, but based on social ownership, selfmanagement and some elements of the market economy. In the rest of Europe, capitalism based on private property continued. Nevertheless, urban growth and development did not differ in the two different social systems. The key reasons for this are common civilization and common heritage.

"The really distinctive marks of the socialist model of urban development are not to be found in specific elements of its structure, but in the system of political, economic and social relations underlying their emergence" [10].

The effects of the duration of socialism have become apparent in the last decade of the $20^{\text {th }}$ century, when socialism ceased to exist, and social ownership was abolished. In urban planning, as a reaction to the former system, the terms 'public' and 'collective' almost disappeared from use, wrongly associated only with the failed socialism, although public and collective are, in fact, bound with the city since its beginnings.

With the Croatian Constitution, which was adopted by the Parliament on December 22 in 1990, social ownership was abolished, and the preconditions for the creation of a new legal system based on civil law and private property rights were established. 
Since this significant change took place, landowners appear as the only drivers of creating new and modifying existing urban plans. Private interests are focused only on a specific area and the city as a whole is not considered and, accordingly, public spaces receive no attention. But as Bernard Huet said: "Architecture is by definition a private and the singular, as the contrary to the city, which is the collective creativity" [11].

\section{DEVELOPMENT OF SPLIT 3}

Founded in ancient times, the City of Split underwent all the same development stages as most European cities. Split has always been on the periphery of the European and international flow of goods and services, but globally is now best known for Diocletian's Palace. Today, Split has approximately 200,000 inhabitants.

Many architects and historians have recognized Split as a notable city and worthy of research, beginning with Palladio and including Robert Adam, J.B. Fischer von Erlach, George Niemann, Jacques Zeiller and Ernest Hébrard. The Scottish architect Robert Adam published the book The Ruins of the Palace of the Emperor Diocletian at Spalatro, accompanied by fine illustrations by C.L. Clérisseau. Much impressed by the Palace, Adam and his brother reproduced some of its elements when erecting the Adelphi building in London, and other constructions in the distinctive neoclassical "Adam style".

Interest in Split in the $20^{\text {th }}$ century shifted to the newly planned part of town, called Split 3. "Split 1 is the old city and Split 2 a new town designed and built in the image of the Ville Radieuse. Split 3 involves a design of streets and pedestrian paths, lined with shops, densely populated and more or less devoid of cars. Its spaces are scaled to people and their preferred patterns of living" [12]. For this reason, many local and foreign professionals visited the city and analyzed the enterprise, some of them several times: Giancarlo de Carlo, Jane Jacobs, Bob Jacobs, Uwe Jan Woltemade, Paolo Borghero, Romano Burelli, Frederick Gutheimanas, Donald Appleyard, Frano Violich, Peter Blake, to name but a few. The features of Split 3 have been described and praised in newspapers, reviews and books, at home and abroad.

At the time when Split 3 was created diverse ideas were present in urbanism: Alison and Peter Smithson wrote the theory Uppercase (1960); Yona Friedman planned Paris Spatial (1960), Tunis Spatial (1960) and Bridge City over the Ärmel Canal (1963); Christopher Alexander put forth his theories in Notes on the Synthesis of Form (1964); the Archigram group planned utopian projects such as Fulham Study (1963), Plug-in City (1964 -1966), Walking City (1964) and Instant City (1968); Paolo Soleri provided projects for about 30 Arkologies; and Candilis, Josic and Woods planned and built Toulouse le Mirail (competition 1962, realisation 1964-1977).

According to the original programme for Split 3, created in 1968, the 341-hectare (ha) area was to include seven local communities and 14,000 apartments for 50,000 inhabitants with: services and facilities such as schools, kindergartens, playgrounds and small clinics; business and commercial enterprises such as department stores, offices, restaurants and other businesses; parking spaces; tourist facilities, including hotels, with a capacity for 5,000 guests; university buildings - the departments of Medicine, Physics and Mathematics, Chemistry, Architecture and Civil Engineering, and Economics; a new business district to supplement the old city centre; and beaches and seafront facilities for sports and recreation.

Split 3 programming introduced a new approach. At the time, a broader society - with its specific organizations like city councils of culture and education and social and health affairs; the Split organization of architects; a city chamber of commerce; political organizations; the Split Construction Enterprise (PIS-Poduzeće za izgradnju Splita) and the like participated with data and proposals. Exhaustive questions on common investment in public programmes and public services (schools, kindergartens) or parking surveys, among other things - were put forward so as to obtain the opinions of potential investors. The general principles for Split 3, established by professionals with the help of the accepted comments and suggestions, were published as guidelines. The whole area envisaged for construction was to be included into the scheme of the entire city, thus departing from the earlier practice of designing several hundred apartments at one time. This meant a longer preparation phase with an expected reduction of both construction time and costs.

The urban concept was developed along the programme guidelines prepared for a state competition held several months earlier. Vladimir Mušič, Marijan Bežan and Nives Starc, authors of the winning concept of Split 3, together with Josip Vojnović, an architect from PIS, introduced comprehensive planning, which included forming a project team whose programmers, planners, technologists, designers and builders permanently interact. Simultaneously, a constant dialogue with the communal decision-making structures took place. The project team worked 'in situ'.

The characteristics that distinguished this urban solution are the following: Split 3 furthers a trend of building eastward, where a concentration of city-centre functions gradually decline or are replaced when they come into contact with the next business district that is part of the neighboring town. Housing and other urban elements gradually fill in the area, in step with the downtrend of the city-centre functions. The designers also introduced a street as the main principle of the whole area. The street has two forms. One is a housing street, running east-west along the direction of Roman centuriation from the first century $\mathrm{AD}$, today visible in the position of some streets in Split. The other is seen in the two larger Dalmatian alleys, running north-south, in the direction of the Cardo of the Diocletian's Palace (Fig. 1).

This principle was joined by another: the arrangement of urban units. It was based on an existent communication grid dating back to the ancient division of the terrain from the first century, of the then outskirts of Split. Parcels were on average 50-60 ha each. Sites of about that size appear as a term and a requisite in urban planning in the early $20^{\text {th }}$ century in the United States (US), and later in Europe and the 


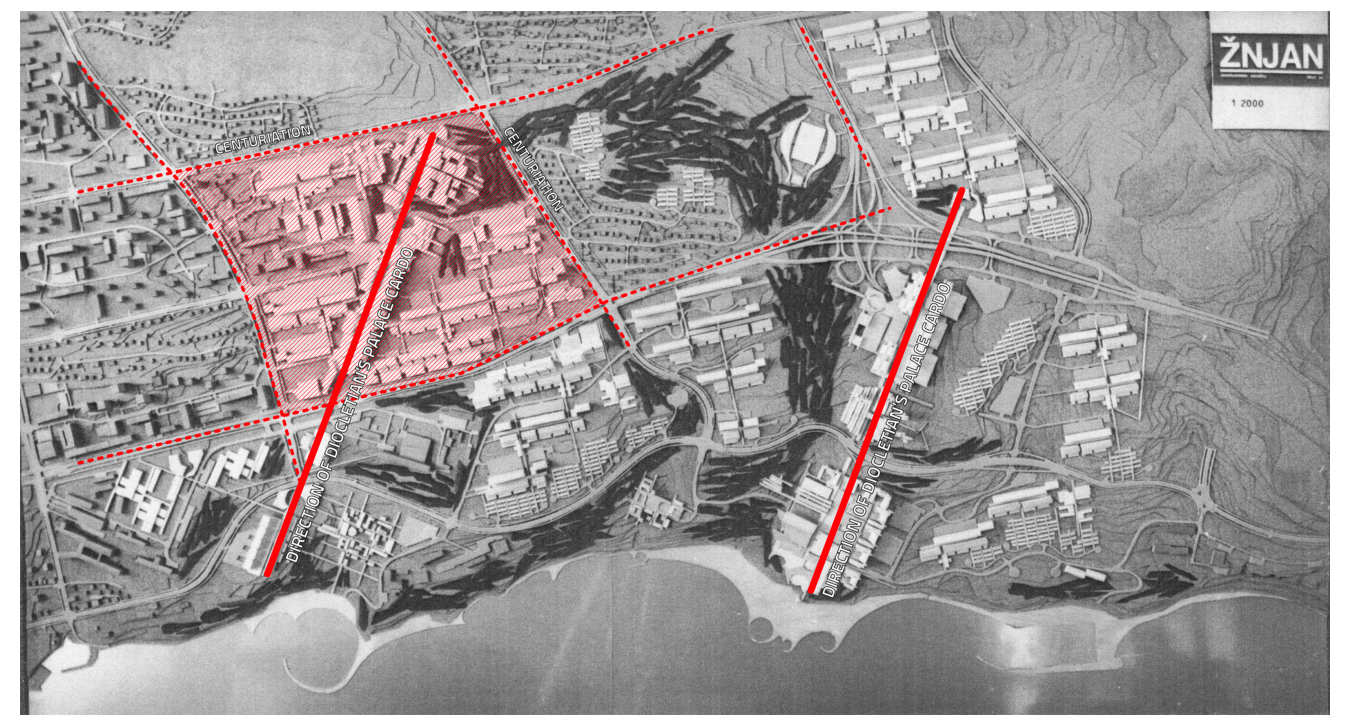

Fig. (1). Analyses of directions and areas of Split 3 public places displayed on the model of the competition entry “Žnjan”, Split 1968 [3].

USSR, in the form of a neighborhood unit that is an urban unit. C.A. Perry (1872-1944) became one of the principal theorists and advocates for the neighborhood unit as a principle element of urban planning. The unit should provide housing for a population for which one elementary school is ordinarily required, its actual area depending upon population density. Perry suggests a unit of 160 acres or 64 ha for about 5,000-6,000 inhabitants, which can vary. Despite controversies and subsequent deviations, the neighborhood unit is still today the criteria used for the comprehensive design of residential areas. Mušič, Bežan and Starc were familiar with the term urban unit and used it in Split 3, which perfectly fit the existing terrain division.

A hundred years later, the United Kingdom's Urban Task Force, headed by Richard Rogers, in its final report proposes typical neighborhood of about the same size to be used in the urban renaissance: "7,500 people to support good neighborhood facilities and good public transport; everyone should be able to walk to their local centre at the distance of up to 540 $\mathrm{m} "$ [13].

In 2012, the Transport Demand Management (TDM) Encyclopaedia of the Victoria Transport Policy Institute, Victoria, Canada, published the article "Road Connectivity", showing the model that takes into consideration the size of 64 ha, which is the same size of C.A. Perry's neighborhood unit. Within the network of roads and pathways, the model uses a distance of 800 to 1000 metres for the minor arterial road and a distance of 400 to 500 metres for the collector road, for about 4,000 residents. "It uses a continuous grid of roads for district and regional connectivity and a discontinuous grid of streets for neighborhood safety. The latter (neighborhood) grid is supplemented by footpaths that connect all streets, turning a neighborhood into a fully connected pedestrian realm" [14] (Fig. 2).

"For example, planning followed the life-space-buildings principles in areas that needed new towns such as the Greek and Roman colonies and in planned medieval towns like Monpazier in the south of France, founded in 1283. Urban planning in later years was also influenced by these principles. In the cities of the Renaissance and the Baroque periods, city space was primarily the starting point for planning, and the same principles can be found in many planned colonial towns in North and South America (...). Thus the lifespace-buildings order can be followed throughout urban history until the recent modernistic period in which buildings took centre stage rather than life and space" [7].

\section{DISCUSSION}

The urban concept of Split 3 introduced an open system that meant that some areas and elements were under utmost control in accordance with the master plan. Those elements, the streets together with an overall communication grid that form urban units, make up the urban design of Split 3 and at the same time, the public spaces. Other elements, mostly architecture, were flexible to a large extent.

From 1968 until 1991, the urban design that is the pattern of the main public spaces was built and dominantly stands out in the image of the whole city. Close linkage within the team and with the broader social system of the time produced a visible step away from the then achievements of urban planning, even under the limited economic conditions in the former Yugoslavia.

During the period from 1968 to 1991, not all marketplaces, garages, promenades, playgrounds, green areas and parks were built. The space left for their construction, during the transition from a single-party system to a market-oriented society, has been reassigned, mostly for housing.

With the adoption of detailed town plans for individual, small-area operations, the advantages of planning Split 3 as an integrated part of the city were lost. In spite of time and 


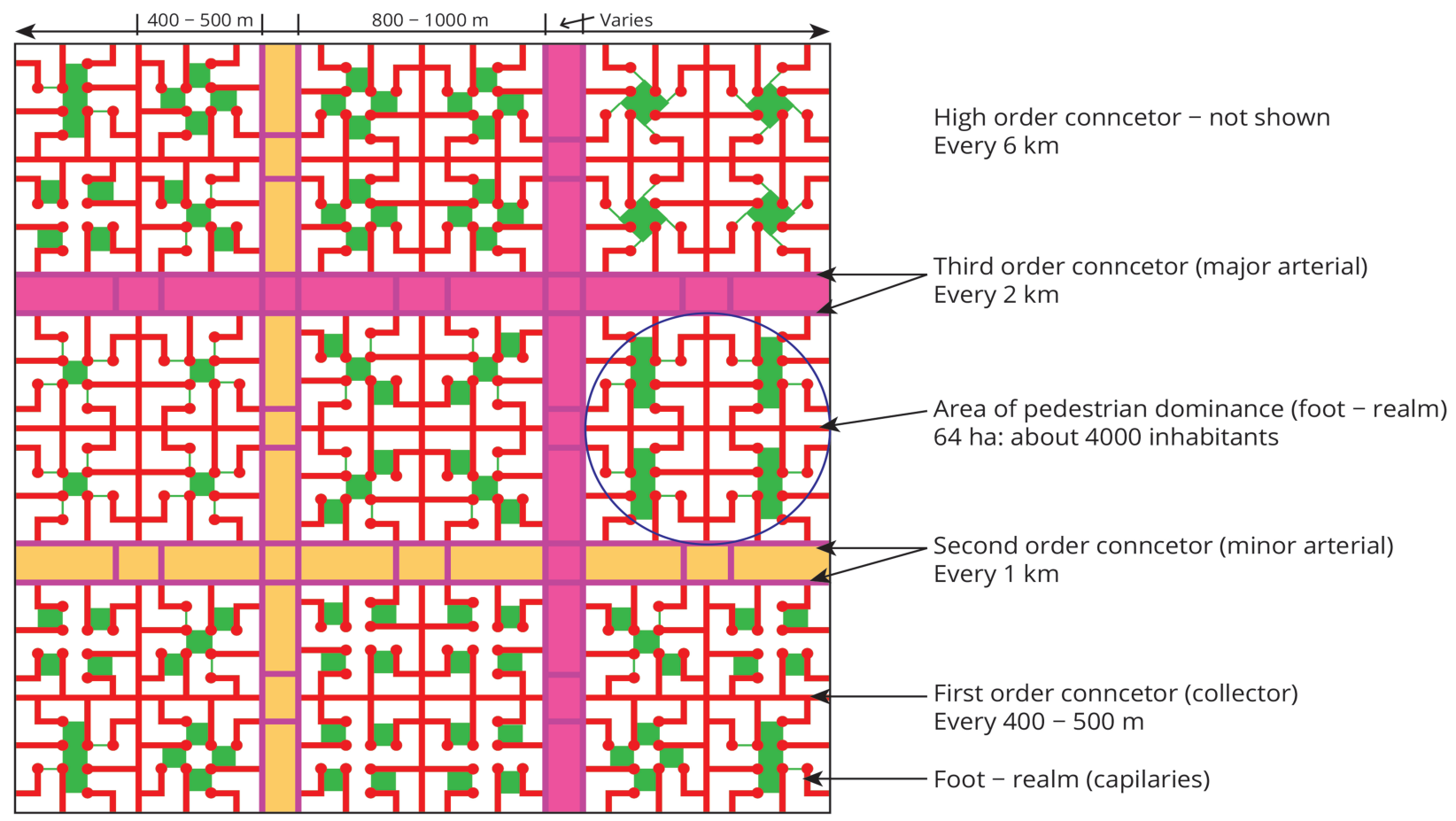

Fig. (2). Fused grid [14].

changes, 40 years after its creation Split 3 has been lived in and worked in intensively. The matrix established then is effective to this day. Split 3 has more of an urban life than any other neighborhood in the city built post-WWII. It is recognizable, easily accessible and satisfies the better part of people's daily needs. Its streets, paths and other public places provide for urban life. Respecting continuity and relying on the existing division of the terrain of the "noble logical diagram" resulted in a visual language and urban armature of the entire area.

A city is not made up of houses but of people. Houses are built in a year, a street in five years, and part of a city in ten or more years. City life will express itself in perhaps 50 years and in a different way than that foreseen by planners. This is why urban planning must be strong and intrusive and at the same time flexible and open - most of which has been achieved in Split 3.

Similarities become evident when analysing the basic approach to Split 3's explicit planning criteria and that of C.A. Perry's neighborhood unit, the typical neighborhood of the British Urban Task Force and the fused grid proposed by the Victoria Transport Policy Institute in Canada.

In regard to the above it follows that the size of the urban unit of between 50 and 60 ha for 6,000 to 10,000 inhabitants with adequate facilities occurs in urban planning for a whole century, and largely coincides with the size of centurias created in antiquity, used in Split 3.

How a structure, which is the result of the method of division of agricultural land, can be contemporary and at the same time over 2,000 years old was shown by the activity of a group of architects, of different nationalities, gathered at
Harvard Project on the City. They produced "basic instructions for installing and configuring a city" [15], adding that "Once you know how cities function in the Roman system, you will have all the necessary information to configure and program your own" [15]. The game was given the name 'How to Build a City'. The authors posed the fundamental question: Can urbanism be learned the way children are taught to read, by the "global method"? According to the practitioners, from the ages of three to five, a child discovers the link of the written word and its meaning through the word's overall or global aspect (like a logo) and through its context of presentation reveals the connection between the written word and comprehensive view of the world, and the child learns to read by playing, without special exercises of articulating syllables. The authors of the game envisioned the global method by which the city is built in the same way. From the $5^{\text {th }}$ century $\mathrm{BC}$ to $5^{\text {th }}$ century AD, across the entire territory of the Roman Empire, in almost all of modern-day Europe, through Turkey, Egypt and North Africa, cities were built the same way. The method was universal. The authors take the Roman method as the foundation of the game, suitable for all times and all conditions, calling it the 'Roman operating system'. This method consists of standardized parts organized in a matrix through the process, which allows permanent but changing urban processes as they are absorbed by the generic pattern.

In Split 3 standardized parts are organized in a matrix, which has the ability to absorb the changing urban processes as they are absorbed in the generic pattern. It is both the contemporary and old structure, built in periods of limited democracy, but operational under the new conditions of capitalism and urban planning demands. 


\section{CONCLUSION}

Views on urbanism are changing. Looking for new and different solutions irrespective of whether or not current ones are good is standard practice. Yet we conducted our research with the idea of learning from the existing and local good practice. We surveyed the elements of Split 3 and whether they can be the basis for planning in the future.

Through our analyses we established that the Split 3 urban unit, which is the neighborhood unit, manifested itself through the distinct urban and architectural form, which is the urban matrix. Its sizes date back to ancient times and have been confirmed in contemporary findings. We considered those to be good reasons to take the Split 3 urban unit and its streets - i.e public spaces - as the basis for future urban planning of small cities.

Urban planning is an act of will, and effort of conscious design. Space is the most valuable thing since it is finite and limited while our needs and wishes are infinite and unlimited. The need for responsible behaviour of experts is indisputable. For this purpose we suggest the use of confirmed knowledge and forms, and they are the following:

Compact urban structure consisting of the urban unit as its structure cell;

Primary streets as both boundaries of urban units and the main traffic arteries, closing rectangles in the size of 50 to 60 ha;

Division of urban units to the secondary streets for local traffic;

Alternative routes for pedestrians in the centre of the urban units, as well as to neighbouring urban units;

The size of the urban unit for 6,000 to 10,000 inhabitants;

Urban units form the grid; several urban units, inside of the grid form the region with 30,000- 40,000 inhabitants.

"Cities are an immense laboratory of trial and error, failure and success, in city building and city design. This is the laboratory in which city planning should have been learning and forming and testing its theories" [1].

The pace of economic, energetic as well as production changes in the world outmatches the pace of planning and the realization of plans in cities. That is why the use of the constants, proposed by this research that would simplify the process of urban development and functioning in small cities, would be appropriate.

Regarding the references, we argue that, "we are not in the field of medicine, biology, astrophysics or electronics, in which the discoveries occur daily and on which we should be notified immediately. On the contrary, in the field of urban and regional planning, it is better to keep ourselves from reinventing. Perhaps it is more important to know that the same thing someone wrote already in 1900 , and not only in $2000 "[16]$.

\section{CONFLICT OF INTEREST}

The author confirms that this article content has no conflict of interest.

\section{ACKNOWLEDGEMENTS}

Declared none.

\section{REFERENCES}

[1] Jacobs J. The death and life of great american cities. New York, USA: Vintage Books, a division of Random House Inc 1992.

[2] Burnham DH. London 1910 in Bacon N E. Design of cities, London, Great Britain: Thames and Hudson 1978.

[3] Kukoč V. Method of urban public places in times of transition as exemplified by split III. PhD Thesis. University of Ljubljana 2013.

[4] Mušič VB. Urbanism - myths and reality. ljubljana, Jugoslavija: Cankarjeva Založba 1980.

[5] Rossi A. Arhitektura grada. Belgrade, Serbia 1992.

[6] Lefvbre H. Urbana revolucija, Belgrade, Yugoslavia, Nolit 1974.

[7] Gehl J. Cities for people, Washington, Colvelo. London: Island Press 2010

[8] Giedion S. Space, time and architecture, Cambridge, Massachusetts: Harvard University Press 1970.

[9] Eveno E, Mestres J-M. Ville numėriques, villes intelligentes? L'Urbanism 2014; 394: 25.

[10] Andrusz G, Harloe M, Szelenyi I. Eds. Cities after socialism. Oxford UK: Blackwell Publishers Ltd 1996.

[11] Huet B. L'architecture contre la ville, AMC 1986, 14:23.

[12] Blake P. Form follows fiasco: Why Modern architecture hasn't worked. USA, Boston: Little Brown \& Co 1977.

[13] Rogers R. Towards an urban renaissance, Final Report of the Urban Task Force Chaired by Lord Rogers of Riversied, E\&FN SPON, London, Great Britain 1999.

[14] http:// www.vtpi.org/tdm/tdm116.htm (June 16, 2012).

[15] Koolhaas R, Boeri S, Kwinter S, Tazi N, Ulbrich Obrist H, Eds. Mutations, Bordeaux, Barcelona, Actar 2000.

[16] Marinović-Uzelac A. Prostorno planiranje. Zagreb, Hrvatska: Dom i svijet 2001 . 